\title{
Decision Maker's Tool: Statistics, the Problem Solver
}

\author{
Faith Cajudo Orillaza, External contributor
}

Faith.Orillaza@westcliff.edu

\begin{abstract}
The primary objective of every investor is to see how his money grows. No matter where one decides to plant or invest his money, there is an inevitable process that follows. The important thing is to closely monitor events and record every detail of information. Unless there is a proper system, issues will build and may become difficult to manage. This is the main reason why there are tools which are necessary to use when planting the seeds for investments. These tools are packed into one parcel and referred to as statistics. The term statistics will refer to descriptive and inferential statistics, probability, parametric and non-parametric tests, time series, and business intelligence. This paper will define statistical gears which are normally used by business managers to gather and analyze data for planning and decision-making. It will further highlight how the elements of statistics can build a strong pillar to run a business and alleviate potential challenges through the use of a tool known as the problem solver.
\end{abstract}




\section{INTRODUCTION}

Problems are a part of running a business. Companies must meet a target return of investment while dealing with daily operational issues and even some unexpected problems or hitches. Becoming seamlessly problem-free is what everyone is after, but it seems impossible to achieve. This is where the problem solver comes into play. To make the goals of a company attainable and achievable, the problem solver, statistics, is essential.

\section{STATISTICS}

In business, problem-solving and making decisions are daily encounters for management teams. Each day, these teams deal with the quantitative analysis of a large amount of data. In order to handle this data, knowledge about statistics is crucial. Statistics includes an understanding of the population under study as well as an analysis and generalization of the information given (Skinner, Patel, Thomas, \& Miller, 2011). Statistics are needed to aid operational activities and solve identified issues.

There are two types of statistics, one is descriptive, and the other is inferential. The former applies numerical measures or graphical methods to organize data and information and describes the types of the sample taken (Marshall \& Jonker, 2010). Since descriptive statistics create a systematic presentation of data and figures, it becomes an easy way for managers to comprehend the given information. Inferential statistics provides a generalization about the population from which random samples are drawn (Van, 2001). The meaning behind the figures is then explained. The decision maker can then formulate conclusions from the given summary of the systematic events analyzed.
When dealing with problems and proofs, the basis must be the common denominator for why a certain decision is made. A reliable manager must be someone who develops his opinion, based on the data analyzed, not simply depending on his viewpoint alone. According to Kutschera (2002), for many people, their prior experiences become a major determinant for how they make decisions. This is not recommended, specifically in a world of figures, where money is involved. The trend of the previous success in business must first be gathered and analyzed prior to making a decision about the next move to take.

Confidence is developed through competence. Competence is acquired through gathering information, knowledge and experience. Competent leaders are not weak or easily intimidated but are powerful when they display an attribute of expertise in the subject of their role (Ramba, 2013). In the United States, one of the leading causes as to why small companies fail is due to incompetent leaders (Valdiserri, 2010). Competence on the part of the decision maker is achieved when a series of supporting data is available. Unless proofs are ready to be evaluated, examined and analyzed, there is no assurance that a particular decision is correct or proper. Therefore, a leader must continue to use the problem solver tool, in order to build competency and confidence. Using this, a leader will be able to manage his entire team well and handle issues logically.

On the other hand, if a leader is neglectful of his duties, specifically regarding finding ways of gathering data or analyzing information, the business will most likely fail. Failed businesses impact the GDP of a country. Headd (2003), explains that $90 \%$ of small 
businesses fail during the first three years of their operation in the United States. When a leader is overwhelmed by the pressure of handling problems, does not conduct a thorough study of the market and sales trends, or is not able to handle the performance and scheduling of delivering goods and services, the nine over ten ratios will surely become applicable.

\section{ProbabiLITY}

Probability is a major player in statistics (Gerhan, 2001). Uncertainties are everywhere, which is not a good thing for business managers. According to Burgin (2012), probability is associated with risk in the area of business. Risk management, as defined by Cross (1995), is the implementation of concepts which are applied and used by other entrepreneurs who succeeded in their business ventures. However, risk management should not only identify a pattern from previous gains, it must also incorporate the application of acquired knowledge.

Generally, in business, the probability of success rates is lower than the rates of failure. A majority of leaders will predict that they will always be able to hit their targets, but this is not usually the scenario. In this particular case, a knowledge of statistics could support the decision-making process by allowing leaders to evaluate uncertainties based on numerical values. The insurance field is an example of the type of industry which handles big data. Different sections within the industry each deal with various policies and issues. Without the application of probability, there would be no system or direction. Plans are generally created based on assumptions, essentially predicting an upcoming condition which has no guarantee (Gitlow, 2001). Businesses can side step this risk of planning with no certainty by basing predictions on the analysis of data prior to developing a plan.

In statistics, parametric and nonparametric tests are essential tools used to analyze the given data. Cohen (2001), explained that a parametric test pertains to the analysis of variance, while a non-parametric test is a ranking test. The former deals with the study of given data with known values for distribution. On the other hand, the nonparametric test is not dependent on its analysis through the sample data, but instead depends on the ordinal, position, and levels determined.

The use of a survey is one way to perform parametric and non-parametric tests. From 2003 until 2015, the investment activity of 144,000 firms in Croatia were reviewed. A parametric test was conducted to check if investors who made a prior investment before the recession were able to survive during this period. It turned out that there was around a $60-70 \%$ success rate for those who made investments (Kovac, Vukovic, Kleut, \& Podobnik, 2016). This information is helpful to investors when they analyze if investing is wise when a recession is approaching. Probability to succeed must be based on past data, which should be reviewed, analyzed, and applied to a given situation.

\section{TIME SERIES ANALYSIS}

Time is a very important parameter in business as time is one of the most crucial elements used to monitor how money is generated. When data is collected, it is gathered at a given period of time (Lind, Marchal \& Wathen, 2017). The record of time helps information to be provided regarding how intervals are obtained, why fluctuations happen, when discrepancies arise, and to determine the extent to which a trend will continue to move in the same direction. 
When a company experiences loss, most of the time a leader will still push to a maximum extent to try and save a business. According to Wu and Young (2002), in order to prevent bankruptcy survival analysis on the available statistical data must be performed. Though survival data is said to be exclusive information, it is otherwise referred to as "censored" as bankruptcy is not even detected at some companies which seem to be performing fine until they are suddenly unable to financially support their operations. That is why time is very important to monitor along with the progress of a business. Forecasting sales versus expenses is a must.

In statistics, there are rules that must be kept to provide information based on correct and accurate data, not that from fixed data. There could be hundreds of rules to follow, but in terms of dealing with statistical process control charts, the 10 commandment rules were shared by Hoyer and Ellis (1996). This type of chart is commonly presented with the inclusion of time. Two of the commandments were written as "Thou shalt not adulterate thy data to make an out-of-control process appear to be in control" and "thou shalt not conceal an out-of-control process from thy supervisor, manager, or customer" (Hoyer \& Ellis, 1996). Data should serve as a guide. Manipulating or adjusting data violates the process of control regulations. Unless these rules are adhered to and followed, a company's system cannot be improved or developed. These rules exist to prevent future issues from impacting an organization.

A control chart is applicable to every type of organization to promote a type of quality control system. Under the process control, the two sources of variability are referred to as natural and assignable. The former is uncontrollable unless a process is revised and modified, while the latter is an outcome of human error. It could be prevented, reduced or removed by analyzing the issue and knowing the cause. An example of human error could be that, supplied materials may have changed, which may require recalibration of the equipment used or any other form of improvement to correct the system (Trujillo, 2018).

In order for a control chart to work efficiently, any outcome that appears in the chart must be transparent followed by an open discussion to mend issues identified in a system. Some companies may just be using a control chart for audit purposes. Points outside the control limit warn the management team that an action plan is needed to improve the identified unruled practice. Any company may pass the audit evaluation, but the actual structure of an operation may suffer from a number of defects. With the use of a control chart and its sets of rules, flaws in a given system could be fixed or even avoided.

Because a time series is about forecasting, the wider the numbers in a given sample of a population, the better. The more information that is given, the more useful the data is in the decision-making process. When consultants are asked to evaluate a sequence of events, they need ample data for the basis of their analysis. Ideally, a minimum of 100 responses to 1,000 responses from a conducted survey or data information must be available (Beam, 2005). For the confidence level, if an examinee would like to get a score of at least $96 \%$ for his periodic exam, out of 50 question items, he should make at most two errors. If an investor is willing to take a risk of losing $30 \%$ of his investment in five years, he should maintain an earning of seven million dollars and above within a five-years period from a $10 \mathrm{M}$ investment. If time is monitored and recorded along with its corresponding activity in an 
organization, a trend could be generated which plays a significant role in estimating future events. This will be very helpful in forecasting probable issues that might arise.

\section{Business INTELLIGENCE USED IN CONCEPT WITH Statistical TeChNiques}

Problems in a business are dealt with through a process of decision-making. Managers in an organization follow an existing ranking. The one working in the operation department and customer relation department, as well as those involved with business associates, competitor activities, human resources issues, or economic situations, handle decision-making on a shortterm basis. They are dealing with the least numbers of data. Moreover, technical managers refer to those who are above the heads of the listed departments, top managers deal with comprehensive decisions based on the numerous amounts of data available for them to analyze. Through business intelligence, all data is converted into information which enables the decision maker to handle every issue objectively. All leaders from top to bottom use business intelligence to develop a systematic process and maximize efficiency. Therefore, the different rankings of managers are intertwined by the use of business intelligence (Zamani, Maeen, \& Haghparast, 2017).

Lastly, organizational flexibility is crucial in decision making. Through business intelligence, market opportunity and threat can be gauged (Chen, 2012). This is proven essential to handle gains and losses. The aforementioned components of statistics are necessary to ensure security on the part of the investor.

\section{CONCLUSIONS}

Overall, problems are everywhere. They may be small and possible to ignore, or huge and seemingly impossible to handle. Companies may not be able to identify the correct decision, unless they adopt the advantage of technology and use it to solicit feedback from their customers, by applying the parametric and non-parametric test, business intelligence, and concepts of statistics.

The main key in every investment is to carefully plan and make informed decisions. This can be done only through being precise, gathering data from the past, analyzing the given trends, and drawing probability to determine one's actual possibility to meet identified targets. Wrong decisions may cost a hundred dollars at the start, but in later days or years may cause the company to close.

Decision-making is dependent on what risks the decision maker is willing to take. For investors, there are four options to choose from: release more money for investment, release a reasonable amount for investment, release a small amount for investment, or stop investing altogether. What is important is to follow the guidelines upon which decisions must be based. It is not through a baseless line of thinking, but it is about going back to the data, the history of data information. From there, the decision maker can make up their minds to execute a plan for how to solve any problem that should arise, mostly by applying and using the principles of statistics, the problem solver. 


\section{REFERENCES}

Beam, C. (2005). Turn quantitative data into meaningful information. Consulting to Management, 16(2), 35-38. Retrieved from https://search.proquest.com/docview/215902686?accountid=158986

Buluswar, M. (2016). How companies are using big data and analytics. Retrieved from https://www.mckinsey.com/business-functions/mckinsey-analytics/our-insights/how-companies-areusing-big-data-and-analytics

Burgin, M. (2012). Integrating random properties and the concept of probability. Integration, 3(2), 137-181. Retrieved from https://search.proquest.com/docview/1626547458?accountid=158986

Chen, X. (2012). Impact of business intelligence and IT infrastructure flexibility on competitive advantage: An organizational agility perspective. Retrieved from https://search.proquest.com/docview/1035336826?accountid=158986

Cohen, M. E. (2001). Analysis of ordinal dental data: Evaluation of conflicting recommendations. Journal of Dental Research, 80(1), 309-13. Retrieved from https://search.proquest.com/docview/209472478?accountid=158986

Cross, W. (1995). Choosing Goals. In Choices with Clout (p. 54). New York, NY: The Berkley Publishing Group.

Franklin, T. (2015). The state of big data. EContent, 38(1), 28-29. Retrieved from https://search. proquest.com/docview/1671016474?accountid=158986

Gerhan, D. (2001). Statistical significance: How it signifies in statistics reference. Reference \& User Services Quarterly, 40(4), 361-374. Retrieved from https://search.proquest.com/docview/217869732?accountid=158986

Gitlow, H. S. (2001). Viewing statistics from a quality control perspective. The International Journal of Quality \& Reliability Management, 18(2), 169-179. Retrieved from https://search.proquest.com/docview/197602174?accountid=158986

Headd, B. (2003). Redefining business success: Distinguishing between closure and failure. Small Business Economics, 21(1), 51-61. Retrieved from https://search.proquest.com/docview/220946575?accountid=158986

Hoyer, R. W., \& Ellis, W. C. (1996). A graphical exploration of SPC - part 2: The probability structure of rules for interpreting control charts. Quality Progress, 29(6), 57. Retrieved from https://search.proquest.com/docview/214734186?accountid=158986

Kenett, R. S., \& Shmueli, G. (2016). From quality to information quality in official statistics. Journal of Official Statistics, 32(4), 867-885. Retrieved from http://dx.doi.org/10.1515/jos-2016-0045

Kovac, D., Vukovic, V., Kleut, N., \& Podobnik, B. (2016). To invest or not to invest, that is the question: Analysis of firm behavior under anticipated shocks. PLoS One, 11(8). Retrieved from http://dx.doi.org/10.1371/journal.pone.0158782

Kutschera, I. (2002). Cognitive style and decision making: Implications of intuitive and analytical information processing for decision quality. ProQuest Dissertations and Theses. Retrieved from https://search.proquest.com/docview/305553574?accountid=158986

Lau, R. S. M. (1996). Evaluating faculty workload: An application of process control charts with supplementary run rules. Journal of Education for Business, 72(2), 94-97. Retrieved from https://search.proquest.com/docview/202818610?accountid=158986

Lind, D. A., Marchal, W. G., \& Wathen, S. A. (2017). Statistical techniques in business and economics. Chennai, India: McGraw Hill Education Private Limited.

Marshall, G., \& Jonker, L. (2010). A concise guide to... descriptive statistics. Synergy, 22-25. Retrieved from https://search.proquest.com/docview/757915317?accountid=158986

Westcliff International Journal of Applied Research. Vol. 2, No. 2. Fall 2018 
Nilson, V. (2016). How companies are using big data and analytics. Retrieved from https://www.mckinsey.com/business-functions/mckinsey-analytics/our-insights/how-companies-areusing-big-data-and-analytics

Skinner, C. G., Patel, M.M., Thomas, J.D., Miller, M.A. (2011). Understanding common statistical methods, part I: Descriptive methods, probability, and continuous data. Military Medicine, 176(1), 99-102. Retrieved from https://search.proquest.com/docview/848242599?accountid=158986

Ramba, C. (2013). Leadership requirements model - competent, confident and agile. Defense Resources Management in the $21^{\text {st }}$ Century. Retrieved from https://search. proquest.com/docview/1477776474?accountid=158986

Trujillo, J. (2018, June 21). Bus 604-VCS3-Thurs (6/21) 6:00 - 8:00 pm PST [Video file]. Retrieved from https://zoom.us/j/872938779?pwd=\&status=success

Valdiserri, G. A., \& Wilson, J. L. (2010). The study of leadership in small business organizations: Impact on profitability and organizational success. The Entrepreneurial Executive, 15, 47-71. Retrieved from https://search.proquest.com/docview/807725904?accountid=158986

Van, D.B. (2003). Descriptive statistics, inferential statistics, rhetorical statistics. Journal of the American Society for Information Science and Technology, 54(11), 1077. Retrieved from http://dx.doi.org/10.1002/asi.10304

$\mathrm{Wu}, \mathrm{C} .$, \& Young, A. (2002). Critical operating problems and survival rates in small firms: A look at small business institute clients. Journal of Developmental Entrepreneurship, 7(1), 1-23. Retrieved from https://proxy.lirn.net/MuseProxylD=mp01/MuseSessionID=0003/zm/MuseProtocol=https/MuseHost=sea rch.proquest.com/MusePath/entrepreneurship/docview/208439398/fulltext/C07917B3AA65453EPO/1?a ccountid $=158986$

Zamani, M., Maeen, M., \& Haghparast, M. (2017). Implementation of business intelligence to increase the effectiveness of decision-making process of managers in companies providing payment services. Journal of Internet Banking and Commerce, 22, 1-24. Retrieved from https://search.proquest.com/docview/1932306914?accountid=15898 